AL IBTIDA: JURNAL PENDIDIKAN GURU MI (2021) Vol 8 (2) : 222-239

DOI: http://dx.doi.org/10.24235/al.ibtida.snj.v8i2.9137

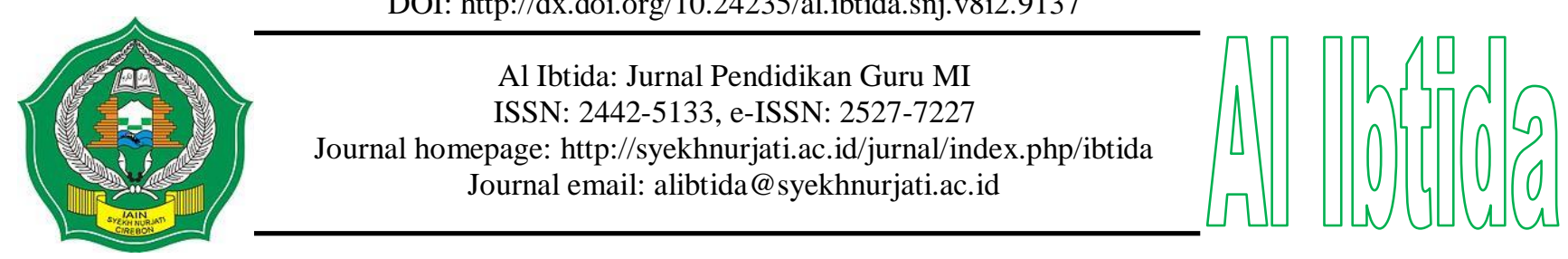

\title{
Improving the Quality of Islamic Elementary School through the Moral Leadership of the Principal
}

\author{
Hartono* \\ *Department of Madrasah Ibtidaiyah Teacher Education, Faculty of Tarbiyah and Teacher Training, \\ Universitas Islam Negeri Prof. K.H. Saifuddin Zuhri Purwokerto, Indonesia. \\ Email: hari_1572@yahoo.co.id

\section{Tamsik Udin**} \\ **Department of Madrasah Ibtidaiyah Teacher Education, Faculty of Tarbiyah and Teacher Training, \\ Institut Agama Islam Negeri Syekh Nurjati Cirebon, Indonesia. \\ Email: tamsikudin@syekhnurjati.ac.id

\section{Onwardono Rit Riyanto***} \\ ***Department of Mathematics Education, Faculty of Tarbiyah and Teacher Training, \\ Institut Agama Islam Negeri Syekh Nurjati Cirebon, Indonesia. \\ Email: onwardono11@gmail.com
}

Received: September 16 ${ }^{\text {th }}, 2021$. Accepted: October 26 $6^{\text {th }}$ 2021. Published: October 30 ${ }^{\text {th }}, 2021$.

\begin{abstract}
This study aims to describe the moral leadership of the headmaster in improving the quality of the Madrasah Ibtidaiyah. Using a phenomenological case study, the data were gathered through interviews, observation, and documentation and then analyzed using three stages, namely data reduction, data display, and data verification. The results reveal that the headmaster is capable of bringing the madrasah to become one of the best madrasahs in Banyumas regency, Indonesia. Every leader has his own passion and leadership strategy. The passion of the headmaster is characterized by a self-energy, a belief based on divine values, and a willingness to learn from other schools. There are three strategies of the headmaster in managing the madrasah: 1) the values to be implemented in the madrasah that presents belief in his leadership passion; 2) communication that is done to build up relationships and motivation towards the vision; and 3) collaboration as a representation of the bonding power in building the strength of the madrasah with the power of the community, in this case the students' guardians. Moral leadership integrated with religious and social attitudes greatly helps the leadership role of the principal.
\end{abstract}

Keywords: moral leadership, strategy, quality of Islamic elementary school. 


\begin{abstract}
Abstrak
Penelitian ini bertujuan untuk mendeskripsikan kepemimpinan moral kepala sekolah dalam meningkatkan mutu madrasah ibtidaiyah. Dengan menggunakan studi kasus dengan pendekatan fenomenologis, data diambil melalui wawancara, observasi dan dokumentasi kemudian dianalisis menggunakan tiga tahap yaitu reduksi data, display data dan verifikasi data. Hasil penelitian mengungkapkan bahwa kepala sekolah mampu membawa madrasah yang dipimpinnya menjadi salah satu madrasah terbaik di Kabupaten Banyumas, Indonesia. Setiap pemimpin memiliki semangat dan strategi kepemimpinannya sendiri. Gairah Kepala Sekolah ditandai dengan energi diri, keyakinan yang dilandasi nilai-nilai ketuhanan, dan kemauan untuk belajar dari sekolah lain sebagai kekuatan pengikat. Tiga strategi kepala madrasah dalam mengelola madrasah adalah: 1) nilai-nilai yang diterapkan di madrasah yang menghadirkan keyakinan akan semangat kepemimpinannya; 2) komunikasi yang dilakukan untuk membangun hubungan dan motivasi menuju visi; dan 3) kolaborasi sebagai representasi kekuatan ikatan dalam membangun kekuatan madrasah dengan kekuatan masyarakat, dalam hal ini wali murid. Kepemimpinan moral yang terintegrasi dengan sikap keagamaan dan sosial sangat membantu peran kepemimpinan kepala sekolah.
\end{abstract}

Kata kunci: kepemimpinan moral, strategi, kualitas madrasah ibtidaiyah.

\title{
INTRODUCTION
}

Quality education is strongly influenced by the quality of the schools as the organizations providing educational services. There are two important factors that could give critical influences on the quality of educational institutions, namely leadership and management. The mechanism designed and implemented in educational services is determined by the leadership and management styles of the heads of the educational institutions (Saiti, 2012).

Certainly, every headmaster in an educational institution has a distinctive leadership style. There are headmasters who adopt authoritarian leadership style, democratic style, liberal style, or spiritual style. The spiritual leadership style is practiced based on the spirit of reviving moral values so that this leadership is equivalent to moral leadership. The moral leadership style of a leader is closely related to the culture of his life (Peterson, et al., 2012). In this regard, we must also talk about the culture of the interlocutor. Culture is formed by environmental conditions influenced by the resulting culture. This is why the moral leadership style of a leader is highly influenced by the condition of the environment he lives. Religious environment that upholds moral values certainly gives a positive influence to the practice of moral leadership (Cherkowski, Walker, \& Kutsyuruba, 2015).

A Shaw and Barry's (2015) popular statement about leadership is interesting to analyze, evaluate, and reflect on today's life. What Shaw said about leadership is in line with a phenomena in the today's society and organizations. Shaw stated that "the reasonable man 
adapts himself to the conditions that surround him. The unreasonable man adapts the surrounding conditions to himself. All progress depends on the unreasonable man" (Shaw \& Barry, 2015).

Moral leadership has a strategic role as a pattern of attitudes and actions in leading (Sari et al., 2017). Moral leadership upholds the aspect of decency. Principal leadership and collaboration with teachers in a democratic environment will lead schools to be more advanced both academically and non-academicly (Malla, 2020). The principal also has a significant role in coordinating, mobilizing, and harmonizing all available educational resources in school (Jaelani et al., 2019). Thus, the view of rationality is influenced by experiences and new thoughts that will develop according to human characteristics (Kozyreva, Lewandowsky, \& Hertwig, 2020). Rational thinking allows a person to find solutions to problems using reasoning to consequential decisions. Principal leadership manages to change, namely religious, professional and humanitarian values, and beliefs (Walid, 2018). In implementing leadership, spiritual beliefs and professionalism are needed.

Rational humans adapt to the surrounding environment, while irrational humans make the environment adapt to themselves. Irrational humans work on changing the environment to adjust to their condition and will. They modify the surroundings according to their needs to develop creativites. Rational humans, on the contrary, simply follow the environment, they even involve in the environmental changes without wanting to transform them into new works that are useful for them, even though they have capabilities to make the changes with their education (Kern, 2020).

What is commonly accepted is that intelligent people are good at adapting to their environment. However, creative people modify their environment to be what they need. They bring progress to the organization they lead, and are able to turn good companies into great companies (Collins, 2018). Leaders who lead in different ways will then create different and unique organizations so that the organizations they lead can become competitive (Galanou \& Farrag, 2015).

The headmaster of Madrasah Ibtidaiyah (Islamic Elementary School) of Ma'arif NU 1 located in Pageraji village of Cilongok subdistrict of Banyumas regency (hereinafter written as MI Maarif NU 1) could be categorized as a "crazy" or "unreasonable" man. This is seen from his distinctive yet creative policy in achieving the goals of his school e.i. becoming the best madrasah in Banyumas regency and beyond. His creative policy is to collect small money through a movement called GISMI PliS (Gerakan Infaq dan Sodaqah untuk Madrasah Ibtidaiyah Paling Seribu/Just a thousand rupiah Infaq and Sodaqah Movement for the 
Madrasah). The collected money is used as an addition to the school's funds obtained from SPP (tuition fee) and BOS (school operational fund) to realize the school's programs. Based on a preliminary study, the collected money from the GISMI PliS program is used to build new classrooms and support activities in preparation for competitions so that the students are more prepared for competitions (data drawn form interview with the headmaster of MI Ma' arif NU 1). Based on an interview with the program manager, the parents do not find this program burdensome, it is very beneficial for the madrasah and students. The students can practice donating their remaining pocket money. Such activities reinforce their social character. Meanwhile, the collected funds could help improving the madrasah's achievement.

GISMI PliS does not act as a main funding resource of the madrasah. Should this project is not implemented the schooling activities of the madrasah is still running properly. The fund from the SPP and BOS funds are sufficient to run the activities. The madrasah's teaching and learning activities can run well without setting up high standards and without ambition to become the best madrasah in the region. The teaching and learning process could be carried out without the programs and facilities that exceed the expectations of students and their parents. MI Ma'arif NU 1 however has a vision to be a high-achieving school. Consequently, the headmaster, vice headmasters, and teachers work on GISMI PliS program. They carry out socialization, fundraising, counting, and monitoring the use of these funds. The GISMI PliS program has shown positive results. MI Ma'arif NU 1 is the most accomplished private MI that has the largest number of students in Banyumas regency. The school always dominates competitions in Banyumas. It is common for students from this school to become champions at the provincial level.

The problem is that such achievement has not occurred yet in other MI in Banyumas. Thus, MI Ma'arif NU 1 Pageraji can be considered capable of competing with SD and MI in the city. This is due to the madrasa principal's passion at the managerial level. The GISMI PliS along with other achievement of the school cannot be separated from the role of the headmaster who is very enthusiastic to make the school one of the best in Banyumas regency and beyond. Theoretically, the discourse on leader's enthusiam cannot be separated form the disourse on leadership passion. The leadership passion is manifested in the strategies taken by a leader in achiving his vision (Day, 2000). Based on the description above, it is very interesting to find answers through empirical research to the questions on how is the leadership passion of the headmaster of MI Ma'arif NU 1, how he finds passion in his organization, and how he implements his leadership strategy. 


\section{METHODS}

This research is a case study with a phenomenological philosophy approach. Data were collected through an analysis of relevant documents of the madrasah, observations, and in-depth interviews. The interview is not only to explore the symptomatic phenomena, but also to find the meaning behind the emerging symptoms (Moleong, 2010). The subjects of this study were teachers who were the main actors of all the processes. The subjects were selected purposively and subject boundaries were determined based on saturated data, so the subjects selected as the research informants could be grouped into: 1) two leaders of the MI (Akhmad Tontowi, Head of Madrasah, Male, 51 years old, 25 years of service, and Andi Wibowo, assistant part of curriculum, Male, 36 years old, 12 years of service); 2) four teachers (Hidayatul Mufidah, 6th grade teacher, 47 years old, civil servant status, female, 20 years of service (Teacher I), Mukson, 4th grade teacher, male, 44 years old, wiyata status, 22 years of service (Teacher II), Yuni Suhartini, 5th Grade Teacher, Female, 49 years old, civil servant status, 23 years of service (Teacher III), Lutfi Widad, 2nd grade teacher, Male, 36 years old, civil servant status, 5 years of service (Teacher IV); and 3) two informants from committee/guardians (Ayuningsih, Committee Manager for 2017/2018 and 2018/2019, Private Job, and Ikmaludin, student guardian status on behalf of Nurhaeni, 41 years old, Private Job)).

Data were collected using interviews, observations, and documentation. Data analysis was carried out through the first stage of data reduction, namely selecting the most appropriate data and deleting data that were out of context, displaying data results in the form of diagrams or paragraphs, data verification or drawing conclusions based on the selected data (Sugiyono, 2010). The theory used as an analytical tool is the Ryan's theory on passion and school leadership strategies that is morally oriented. 


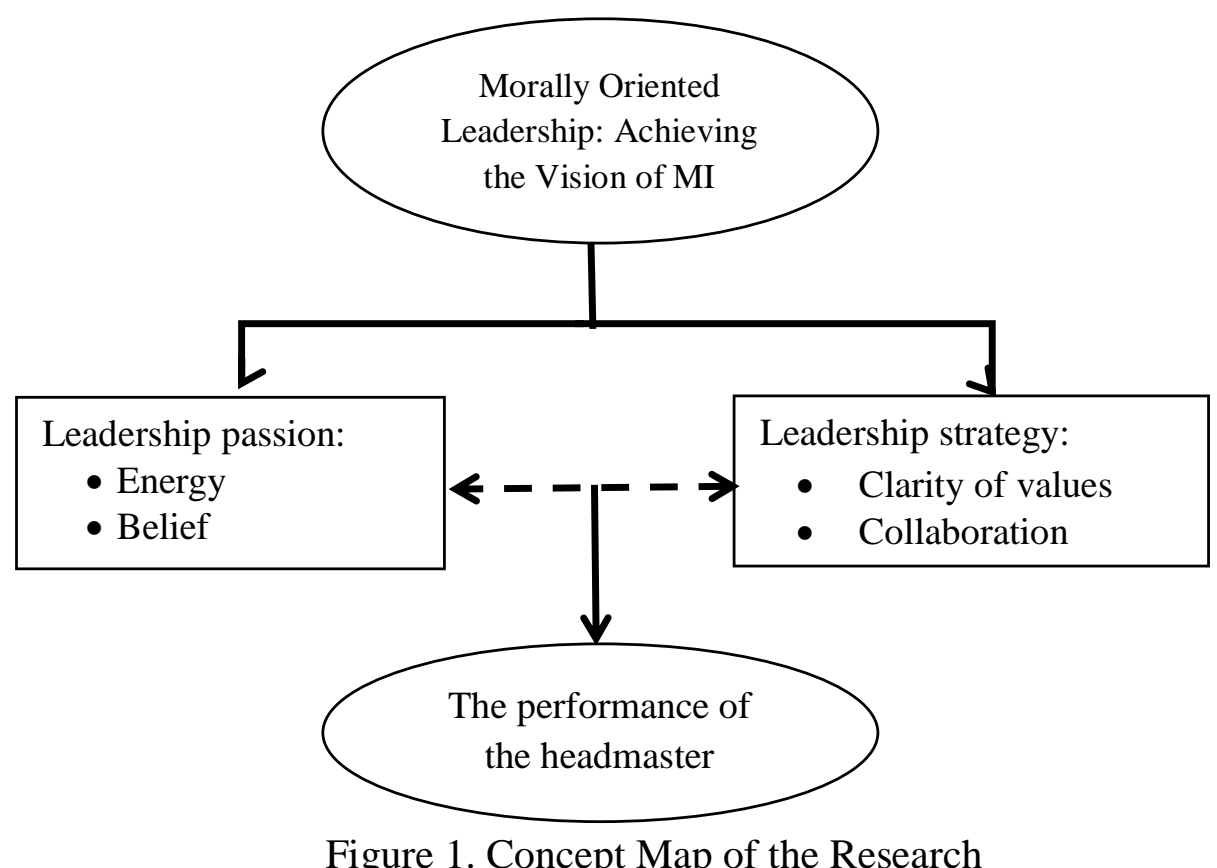

Figure 1. Concept Map of the Research

\section{RESULTS AND DISCUSSION}

The various achievements and progress achieved by MI Ma'arif NU 1 cannot be separated from the quality leadership of the headmaster, namely integrating passion into leadership strategies. The combination of the two will create a morally oriented leadership, namely leadership based on good considerations within a person, so that hard work is an initiative that arises from within a person (Ryan, 2008), not solely due to external factors. Work is not only performed for fulfiling the demands of the surroundings, it is one's own desire based on careful consideration of good and bad. This leadership type can only be formed within a leader when he/she has passion for leading (Egan et al., 2017).

\section{The Value of The Principal's Moral Leadership}

MI Ma'arif NU 1 has an aspiration to become the best private Islamic Elementary School in Banyumas regency and beyond. The headmaster has been conveying this vision to the school committee, teachers, students, parents, and the public in various events and meetings. He hopes by doing so, the aspiration is well-informed to the school's stakeholders, it becomes a shared dream of everyone involved in the school, and gets a full-support from all of them (A. Tantowi, interview, May 2020). The headmaster of MI Ma'arif NU 1 is an active and loyal member of Nahdlatul Ulama (one of the biggest mass organization in Indonesia), and the madrasah he leads is established under the petronage of the organization. Therefore, he has a personal connection to the school that he dedicated his life in advancing the quality of the madrasah. This is in line with the Gronn's (2009) statement that a leader's love for 
his/her organization will result in a totality of the leadership. The totality will then form passion in work.

Every leader certainly has a passion for work and is capable of showing it to the people that he leads so that the people in his organization could gain the same passion in their works. Passion in leading is defined as an enthusiasm possessed by a leader to his subordinates with an aim of inviting them to adopt the same passion in achieving the goals of the organization (Ryan, 2008). Realizing a high-achievig madrasah requires a headmaster to possess not only passion in work and leadership, but could also show that passion to his surroundings. Collins' (2018) research reveals that the transformation of a small company into a great one is highly driven by the passion in work of the whole workers of the company, form the top position (leaders) to the workers (Collins, 2018). Collins' depiction is found at MI Ma'arif NU 1 where the headmaster is very passionate in his works and leadership. He continuously invites the people he leads to find passion for work and life. Everyone involved with the madrasah knows the profile of their leader very well and are eager to follow his instruction. Therefore, changes and achievement are recorded at MI Ma'arif NU 1 under his leadership (A. Tantowi, interview, May 2020).

The teachers are well aware that their leader is very passionate about his work. This has encouraged them to be passionate about work too (Mukson, personal communication, May 2020). Theoretically, passion becomes a strong basis for a leader to bring about changes, although this potential is still determined by how the person uses it in a strategic context (Ryan, 2008). The passion of the headmaster of MI Ma'arif NU 1 develops with the cultural similarity between him and those whom he leads. The headmaster and his people are all active members of NU; they have similar religious viewpoint and practice the same culture. This similarity according to a managerial point of view has resulted in a common vision and have implications for the similarity of motivation at work (Stam et al., 2009). According to Ryan (2008), self-passion involves aspects of energy, belief, and bonding power (Ryan, 2008). The description of these three aspects is as follows:

First, energy as a change maker. Everyone who has a high passion usually has a strong energy. Energy is one aspect of passion that has a transforming power. Energy is a transforming force that is inherent in a person. Its function is to change something. Someone with a good leadership passion always has a strong energy to always make changes (By et al., 2012). Whatever is owned by a person is actually an energy that can be used to change situations outside of himself, for example, physical strength can change something with his hands, the mind can change the direction of a madrasa with ideas, spiritual can change 
something with prayer or hope in a higher power, feelings can change something by building strong self-optimism, and others (Ryan, 2008).

The teachers expressed that the headmaster has a fit and healthy physical condition that allows him be highly involved in many activities inside the school (I. Solihah, interview, May 2020). The headmaster has a Master degree in Islamic Education. He is able to make right decisions reasonably (H. Mufidah, interview, May 2020). This illustrates that the headmaster has the ability to solve madrasah's problems scientifically. With his knowledge, he is able to influence others to follow his vision. The ability to solve organizational problems through a scientific approach is very important for educational leaders in the current era of the industrial revolution 4.0 where everyone do not only want openness but also scientific facts (Roux, 2020).

Spiritually, the headmaster is a person who is a very close to religious traditions, especially those following NU's teaching. He believes that there is a divine power far above the humans' capability that determines their life. Therefore, he turns all his matters to that power when doing his responsibilities as a leader (A. Tantowi, interview, May 2020). This is in line with Mitroff's research which states that many important decision makers in American companies pray or worship first before making decisions (McGhee \& Grant, 2017). Praying means asking for help from other power. Through this, the affairs being carried out are running very smoothly or decisions being taken are in a right direction based on His knowledge. Spirituality, combined with physical strength, thought, and feeling is actually a power to change something (McGhee \& Grant, 2017). In other words, these forces actually store energy to change something.

Second, belief as a core strength. The belief aspect of a leader's passion is his/her core principal in managing and encouraging his/her collagues to achieve optimal results (Ryan, 2008). The headmaster of MI Ma'arif NU 1 puts amanah (trust) as the basic principle of his leadership and ikhlas (sincerity) as the operational value of his organization in an effort to meet the customers' satisfaction. Customer satisfaction is a basic consideration in his leadership; it is where the journey of achieving the targets e.i. becoming the best MI in Banyumas and beyond is started (A. Tantowi, personal communication, May 2020). This policy of upholding customer satisfaction showed that he leads the school by applying a total quality management approach. According to this approach, customers' needs have to be satisfied, in this case, by providing the best educational services possible (Wiyani, 2019).

Third, amanah (spiritual mandate) as the basic leadership principle. The headmaster of MI Ma'araif NU 1 has a specific understanding on becoming a leader. He believes that 
becoming a leader is an amanah (mandate) from Allah that has to be performed in the best possible and most honest way. When he accepted the position, he received an amanah that was bound in a commitment with God to perform the role. The amanah carries logical consequences that he is obliged to carry out the functions as the headmaster of the madrasah (Mukson, personal communication, May 2020). The headmaster stated that his appointment is a mandate with responsibilities lie behind it. His leadership must not disappoint those who gave the mandate namely the foundation's board of trustee, teachers, staff, students, parents, and the founders of the madrasah (A. Tantowi, personal communication, May 2020).

The headmaster believes that the promotion of becoming a headmaster is an amanah. Every amanah must be carried out with a full responsibility. The responsibility is not only to those who directly gave the position, but also to those who made it possible for the position (indirect amanah givers), namely the founders of the madrasah, both dead and alive. The headmaster's emphasis on the responsibility to the ancestors implies a responsibility that puts moral ahead of formal responsibility. Moral responsibility puts forward self-awareness, love, and courage. Self-awarness is the awareness that he has to do his best in his current position; he has to love the madrasah that he leads, and he has to have the courage to take risks and consequences such as having to work more than the normal working hours (A. Tantowi, personal communication, May 2020). The responsibility that is put forward by the headmaster makes his leadership touches moral dimension (Davidson \& Hughes, 2020). The implication is that when he can lead responsibly and uphold moral values; thus excellent educational services could be realized (Wiyani, 2020; Nurhayati et al., 2019).

The headmaster expressed that the motivation in leading is a belief that when responsibilities are carried out accordingly, any tasks can be accomplished professionally; most importantly, they could provide benefits to others. According to him, the essence of life is to be beneficial for others. This moral value must be adered to and be taught to the people in his organization so they do not only fulfill the workloads but also provide benefits to others (A. Tantowi, personal communication, May 2020). The belief and self-actualization of the headmster implied that he adopt a goal-based management model (Das et al., 2018) in his leadership.

When an amanah is perceived by the amanah recipients as a responsibility that should be carried out with moral principles, what develops are efforts to not disappoint the parties who handed the amanah. The headmster stated that the current teachers are privileged; they do not have to go through hardship in establishing the madrasah. They just need to do their jobs continuing the development of the madrasah. This should be easier to do, and must be 
done as well as possible so that the predecessors, madrasah managers, and the foundations are not disappointed with the current and future state of the madrasah (A. Tantowi, personal communication, May 2020).

Working to not disappoint the predecessors and the amanah givers (managers) could be interpreted reversely: pleasing them. The logical consequence of the employee working hard is that the madrasah management will be pleased. This condition is reciprocal law where all parties please each other. This is in line with Allah's saying in Surah Al-Bayyinah verse 78, "Indeed, those who believe and do good - they are the best of all beings. Their reward with their Lord will be Gardens of Eternity (Jannat 'Adn).... Allah is pleased with them and they are pleased with Him...."

The headmaster further noted that when he started running the organization, he was certain to give the best work performace with maximum outputs (benefits for others). Hopefully, the works will be rewarded by God for him and for the educational institution he leads (A. Tantowi, personal communication, May 2020).

Fourth, ikhlas (sincerity) as the basic operational value of the organization. When ikhlas becomes the basis of a leader's attitude, he/she will consequently carry out his/her leadership duties with full responsibility, both to God as the highest amanah giver, foundations, government, founders, and others who have trusted him/her with the position.

The headmaster of MI Ma'arif NU 1 strengthens himself with ikhlas in carrying out the operational works of the madrasah. Ikhlas normatively is defined as a belief that comes from the teachings of Islam which makes God as the starting point and goal of every human act. Work is no longer fully based on the amount of reward given by superiors to subordinates, but it is based on sincerity to fulfill the mandate. (A. Tantowi, personal communication, May 2020). This, at MI Ma'arif NU 1, is referred to as sincere work. If the employees work sincerely, their lives will be filled with blessings. The headmaster stated being sincere (ikhlas) is doing the best work that does not rely on direct rewards in the form of money. Sincerity is synonymous with blessings in life (A. Tantowi, personal communication, May 2020).

In addition to carrying out the given obligations in the best possible way, other manifestations of ikhlas according to the teachers at MI Maarif NU 1 is to have a strong principle and amanah (truthful) attitude in living the organization. Therefore, the main principle in carrying out various activities at the madrasah is ikhlas attitude, namely being discipline and full of responsibility. The responsibility is not only to the government and guardians of the students, but also to the predecessors who had struggled in establishing the 
madrasah (I. Solihah, personal communication, May 2020). The successor of MI Ma'arif NU 1 has the obligation to run and further develop the educational institution (H. Mufidah, personal communication, May 2020). An example of responsibility carried out as an elaboration of ikhlas attitude is to work wholeheartedly characterized by totality until the work exceeds the standards (Machlis \& Jarvis, 2020).

Sincere work according to the headmaster is manifested in the accomplisment of the obligations until unconsiously exceeding the standard, working more than the given responsibility. Working sincerely can be interpreted as working with a total service. The total service requires secrifice. Working exeeding the given responsibility is the secrifice done in regards to total service. By carrying out obligations beyond the salary received, blessings will be obtained by the person (A. Tantowi, personal communication, May 2020).

Through advices in regular meetings and exemplary in daily activity, the headmaster invited the teachers to work sincerely in order to get blessing. A teacher conveyed his belief that he could get blessing if he carries out his obligations by exceeding the standard. He added that sincerity must be trained (Mukson, personal communication, May 2020). Another teacher stated that he strongly believes that Allah will reward him with goodness if he does something sincerely. These beliefs are often emphasized by the headmaster to the teachers. This emphasis becomes an important part considering that the institution does not have enough capacity to pay teachers of an adequate standard (H. Mufidah, personal communication, May 2020).

Fifth, bonding power. An essential aspect of the leadership passion of an organizational leader, in addition to energy and strong self-confidence, is bonding power. Bonding power is the willingness of a leader to learn and build relationships with others (Ryan, 2008). In the context of madrasah leadership, a leader needs to be willing to learn from experience and build network with relevant people or institutions to bring about more advanced madrasah (Assis-Dorr et al., 2012). The headmaster of MI Ma'arif NU 1 revealed that he follows the development of high achieving madrasahs and actively builds friendships with them for the sake of progress to be adopted by the madrasah he leads. This is one of the efforts to make MI Ma'arif NU 1 the best madrasah in the region (A. Tantowi, personal communication, May 2020).

The headmaster of MI Ma'arif NU 1 has a high willingness to learn. For him, learning does not have to go directly to the place of learning, but can be through information obtained through friends, parents, and through reading or hearing from the media. In developing MI Ma'arif NU 1, Al-Irsyad school in Purwokerto among the referred schools to learn from. For 
instance, students of Al-Irsyad Elementary School always dominate every championship held in Banyumas regency. When asked about the management strategy, Al-Irsyad's headmaster conveyed that the students are prepared intensively long before the competition; an adequate funding for this preparation is provided (A. Tantowi, personal communication, May 2020). Learning from the success of Al-Irsyad, the headmaster of MI Ma'arif NU 1 contends that the students must be prepared through careful trainings for competitions with sufficient funding in order to become champions in future competitions. To prepare the students and sign them up competitions, budget is needed. Since the students' tuition fee is only 80,000 per month, it is necessary to raise voluntary funds for this projects.

As an educational institution managed by NU, the headmaster is aware that the strength of the madrasah is NU congregation who are fond of infaq and alms giving activities. All parents and students are invited to give alms every day with small money of Rp. 1,000 per day into the moneybox. Each student is given a plastic moneybox by the madrasah at the beginning of the month. The boxes are then collected at the end of the month. This movement was named 'GIS-MI PliS' which stands for Gerakan Infaq Sodaqoh untuk MI Paling Seribu (Just a thousand rupiahs Infaq and Sodaqoh for MI Movement). This movement is very helpful for the operational financial needs of the madrasa such as creating new classrooms or activities to prepare for competitions.

The 'GISMI PliS' program that has been running for around 7 years and the active participation in competitions outside the madrasah indicate that the headmaster of MI Ma'arif NU 1 is able to build bonding power very well. The power of establishing relationships is used to manage the madrasah to compete with other superior schools in the city. The leadership of the madrasa principal, who views relationships with other institutions as important, has made him learn a lot from the success of other heads of madrasah. The strength of the headmaster in establishing relationships can enhance the madrasah's competitiveness (Wiyani, 2018).

\section{Strategies in Implementing the Principal's Moral Leadership}

The passion of the Headmaster of MI Ma'arif NU 1 will not be effective if it is not balanced with the appropriate strategy for achieving the goals of the madrasah. The passion consists of self energy, belief, and bonding power in the strategic operations (Ryan, 2008). There are several strategies applied by the headmaster of MI Ma'arif NU 1 in leading the madrsah.

First, the clarity of values strategy. The implementation of clarity of values at MI Ma'arif NU 1 Pageraji are: First, Declaring that the position as headmaster is an amanah 
(mandate). By declaring that the postition is an amanah, all works are oriented to the value of ikhlas (sincerety). Thus, other people know that the values of amanah and ikhlas are the basic values adhered to by the headmaster and other positions in the madrasah (A. Tantowi, personal communication, May 2020). A teacher confirms that the headmaster conveyed that his position is an amanah. He does not only receive an assignment from his superiors, but also an assignment from God. By adhering to this value, it is easy for the headmaster to perform the responsibilities attached to this position $(\mathrm{H}$. Mufidah, personal communication, May 2020).

Second, interpreting ikhlas (sincerity) contextually. As an institution under the petronage of NU, MI Ma'arif NU 1 is practicing a belief of blessing and considering it very important in life. The headmaster, teachers, and educational staff emphasize that blessings are the result of sincere works. Being sincere in work will not only give money to the doers, it will also give them blessing in life. The teachers revealed that the mainstay word often conveyed by the headmaster to motivate the teachers is blessing, sincere means blessing (Mukson, personal communication, May 2020). Conveying that "sincere means blessing" is an effort to make the value of sincerity easier to accept and implement, because the term blessing is very close to the lives of the people inside and outside MI Ma'arif NU 1 since they adopt NU culture. Meanwhile, in reality they feel happiness and peace as a result of working with full sincerity. As conveyed by the headmaster, work must be done sincerely and live must be blessed. Blessings cannot be measured by money. Blessing in a family can be in the forms of obedient children, healthy, and others (A. Tantowi, personal communication, May 2020).

Third, making himself a motivator for madrasah's people. One of the duties of a leader is to motivate his members (Woodward \& Shaffakat, 2014). The results showed that the head of MI Ma'arif NU 1 was able to raise the awareness of the teachers and education staff to work optimally, even though the rewards they receive are not like civil servants. Through words and action, the headmaster encourages his members to work hard. The headmaster motivates his members in various occasions, for example Monday morning gathering, teacher/educational staff meetings, meeting in the headmaster/teacher's room, religious lectures outside of school, or other places that can inspire the madrasah people to work hard. A teacher confirms that the headmaster always encourages the teachers on various occasions that sincerity will bring blessings (I. Solihah, personal communication, May 2020).

Second, Communication Strategy. At first glance, communication is a simple aspect that everyone does all the time and feels that it does not bring much change, but basically 
change can occur with the support of positive communication between organizational stakeholders (Christensen, 2014). Various scientific studies on communication show the opposite fact, namely that many great leaders fail in leading because they are not able to communicate well (Salem, 2008).

The headmaster of MI Ma'arif NU 1 has a high passion for leadership and has an effective communication strategy able to touch the feelings of teachers, education staff, students, and others so that he could successfully invite them to bring progress to the madrasah. The communication strategies built include: (1) Strengthening the articulation of words that become messages in communication. The headmaster is concerned about the clarity of the words he uttered when talking to people or giving a speech. This clarity is the beginning of the success of a communication process. The teacher revealed that in order to get clarity on the message, the headmaster "delivered the message slowly followed by expressions according to the context of the word that became the message". His words or invitations arouse awareness or touch feelings, so that his messages can be received and then become shared attitudes and behavior (Mukson, personal communication, May 2020).

(2) Accentuating certain values when communicating. Accentuation of the words to be conveyed when communicating with madrasah people is done by repeating the words that are the core of the message. A teacher confimed that the headmaster always repeated words that he wanted to carry out together and become a shared value. Words that always get accentuated with repetitions of pronunciation are the value of sincerity and blessing. The words "sincere and blessing" are the main messages in his leadership communication to become the best private madrasa in Banyumas. This series of communication is carried out consistently to provide a strong encouragement to believe in a shared value of the madrasa $(\mathrm{H}$. Mufidah, personal communication, May 2020). Positive communication will result in the actualization of positive values in an organization (Hallinger \& Heck, 2010).

(3) Collaboration Strategy. The collaboration strategy emerged from the belief of the headmaster of MI Ma'arif NU 1 is that working should not be done to compete with other parties but it should be done to collaborate with them to realize respective goals (Kramer \& Crespy, 2011). The headmaster was aware that MI Ma'arif NU 1 was located in a village that was economically included in the lower class group, so that the madrasah could not set a high tuition fee. This condition has hindered the efforts of the madrasah to become the best madrasah in Banyumas regency. Realizing this condition, the headmaster chose to collaborate with the students and their guardians to voluntarily put small money of IDR 1,000 per day from the daily pocket money to be put in moneybox (I. Solihah, personal communication, 
May 2020). According to the guardians, the program is not burdensome, because "what is put aside was small change or the rest of the child's pocket money which is often left behind". The moneybox is distributed by the project administrators at the beginning of the month then it is handed back to them at the end of the month. (H. Mufidah, personal communication, May 2020).

GISMI PliS is an important financing source of the madrasah in addition to SPP (tuition fee) and BOS (school operational fund). Gismi PliS is designed not only to raise money, but also to train students to become accustomed to donating, giving charity, and being responsible for themselves and their environment" (interview with the administrator). These habits can shape the characters of caring for the environment and strong responsibility for the students. The emphasis of the program is "building awareness of students and parents"; it is not mandatory (interview with the deputy of headmaster) so that the results of GISMI PliS each month vary from one student to another. However, the average change collected every month is 12 million rupiah, at the beginning of the program it reached 22 million rupiah. This collaboration was able to finance students' competition activities and could even be used to build a nice classroom. That intellectual capital was positively and significantly related to the organization performance (Abualoush et.al (2018).

\section{CONCLUSION}

The leadership of the principal of MI Ma'arif NU 1 Pageraji Cilongok Banyumas has unique characteristics and is able to create alternative solutions to problems so as to improve the the school's reputation. The principal's moral leadership is attitude, action, and belief in facing problems through patience and struggle. Leadership passion does not guarantee the success of an institution in achieving its vision and mission. Leadership passion will lead to success if it is followed by the appropriate strategy to achieve the targets. And the strategy is derived from the passion of the leader of the institution. The leadership strategy at MI Ma'arif NU 1 Pageraji Cilongok Banyumas to realize its vision is an operational derivative of the headmaster's passion. 


\section{REFERENCES}

Abualoush, S., Masa'deh, R. E., Bataineh, K., \& Alrowwad, A. (2018). The role of knowledge management process and intellectual capital as intermediary variables between knowledge management infrastructure and organization performance. Interdisciplinary Journal of Information, Knowledge, and Management, 13, 279-309. https://doi.org/10.28945/4088

Assis-Dorr, H., Palacios-Marques, D., \& Merigó, J. M. (2012). Social networking as an enabler of change in entrepreneurial Brazilian firms. Journal of Organizational Change Management, 25(5), 699-708. https://doi.org/10.1108/09534811211254581

By, R. T., Burnes, B., \& Oswick, C. (2012). Change Management: Leadership, Values and Ethics. Journal of Change Management, 12(1), 1-5. https://doi.org/10.1080/14697017.2011.652371

Cherkowski, S., Walker, K. D., \& Kutsyuruba, B. (2015). Principals' Moral Agency and Ethical Decision-Making: Toward a Transformational Ethics. International Journal of Education Policy and Leadership, $10(5), \quad$ n5. https://doi.org/10.22230/ijepl.2015v10n5a572

Christensen, M. (2014). Communication as a Strategic Tool in Change Processes. International Journal of Business Communication, 51(4), 359-385. https://doi.org/10.1177/2329488414525442

Collins, J. (2018). Good to Great. Gramedia Pustaka Utama.

Das, S. R., Ostrov, D. N., Radhakrishnan, A., \& Srivastav, D. (2018). A New Approach to Goals-Based Wealth Management. SSRN Electronic Journal. https://doi.org/10.2139/ssrn.3117765

Davidson, F. D., \& Hughes, T. R. (2020). Moral Dimensions of Leadership. In F. D. Davidson \& T. R. Hughes, Oxford Research Encyclopedia of Education. Oxford University Press. https://doi.org/10.1093/acrefore/9780190264093.013.785

Day, D. V. (2000). Leadership development: A review in context. Yearly Review of Leadership, 11(4), 581-613. https://doi.org/10.1016/S1048-9843(00)00061-8

Egan, R., Turner, M., \& Blackman, D. (2017). Leadership and Employee Work Passion: Propositions for Future Empirical Investigations. Human Resource Development Review, 16(4), 394-424. https://doi.org/10.1177/1534484317724634

Galanou, A., \& Farrag, D. A. (2015). Towards the distinctive Islamic mode of leadership in business. Journal of Management Development, 34(8), 882-900. https://doi.org/10.1108/JMD-09-2014-0096

Gronn, P. (2009). Leadership Configurations. Leadership, 5(3), 381-394. https://doi.org/10.1177/1742715009337770

Hallinger, P., \& Heck, R. H. (2010). Leadership for Learning: Does Collaborative Leadership Make a Difference in School Improvement? Educational Management Administration \& Leadership, 38(6), 654-678. https://doi.org/10.1177/1741143210379060

Jaelani, A., Patimah, P., Sanusi, U., \& Arifuddin, A. (2019). The Implementation of Principal Managerial Competence for the Primary School Student Discipline. Universal Journal of Educational Research, 7(8), 1832-1838

Kern, A. (2020). Human Life, Rationality and Education. Journal of Philosophy of Education, 54(2), 268-289. https://doi.org/10.1111/1467-9752.12412 
Kozyreva, A., Lewandowsky, S., \& Hertwig, R. (2020). Citizens versus the internet: Confronting digital challenges with cognitive tools. Psychological Science in the Public Interest, 21(3), 103-156. https://doi.org/10.1080/13546783.2013.845605

Kramer, M. W., \& Crespy, D. A. (2011). Communicating collaborative leadership. The Leadership Quarterly, 22(5), 1024-1037. https://doi.org/10.1016/j.leaqua.2011.07.021

Machlis, G. E., \& Jarvis, J. B. (2020). Totality: A Foreword (pp. vii-xiv). University of Chicago Press. https://doi.org/10.7208/9780226542195-001

Malla, H. A. B. (2020). Implementation Of Madrasah Head Leadership Communication In The Development Of Religious Characters. Al-Mishbah: Jurnal Ilmu Dakwah dan Komunikasi, 15(2), 147-162. https://doi.org/10.24239/al-mishbah.Vol15.Iss2.158

McGhee, P., \& Grant, P. (2017). Using spiritual intelligence to transform organisational cultures. EJBO: Electronic Journal of Business Ethics and Organizational Studies.

Moleong, L. J. (2010). Metode Penelitian Kualitatif. Rosda.

Mufidah, H. (2020, Mei). Pendapat Guru tentang Kepemimpinan Moral Kepala MI Ma'arif NU 1 Pageraji Cilongok Banyumas [Tape Recorder].

Mukson. (2020, Mei). Pendapat Guru tentang Kepemimpinan Moral Kepala MI Ma'arif NU 1 Pageraji Cilongok Banyumas [Tape Recorder].

Nurhayati, T., Masnun, M., Udin, T., \& Arifuddin, A. (2019). The Implementation of Principal Managerial Competence for the Primary School Student Discipline. Universal Journal of Educational Research, 7(8), 1826-1831

Peterson, S. J., Walumbwa, F. O., Avolio, B. J., \& Hannah, S. T. (2012). RETRACTED: The relationship between authentic leadership and follower job performance: The mediating role of follower positivity in extreme contexts.

Roux, M. (2020). Leadership 4.0. In J. Reams (Ed.), Maturing Leadership: How Adult Development Impacts Leadership (pp. 7-35). Emerald Publishing Limited. https://doi.org/10.1108/978-1-78973-401-020201003

Ryan, W. (2008). Leadership with a Moral Purpose: Turning Your School Inside Out. Crown House Publishing Limited.

Saiti, A. (2012). Leadership and quality management. Quality Assurance in Education, 20(2), 110-138. https://doi.org/10.1108/09684881211219370

Salem, P. (2008). The seven communication reasons organizations do not change. Corporate Communications: An International Journal, 13(3), 333-348. https://doi.org/10.1108/13563280810893698

Sari, I. N., KH, A. S., Ulfatin, N., \& Arifin, I. The Teacher'Perception on Leadership Characteristic for Moral-Spiritual among Teachers and Headmasters. IOSR Journal Of Humanities And Social Science, 22(6) https://doi.org/10.9790/0837-2206072629

Shaw, W. H., \& Barry, V. (2015). Moral issues in business. Cengage Learning.

Solihah, I. (2020, Mei). Pendapat Guru tentang Kepemimpinan Moral Kepala MI Ma'arif NU 1 Pageraji Cilongok Banyumas [Tape Recorder].

Stam, D. A., van Knippenberg, D., \& Wisse, B. (2009). The role of regulatory fit in visionary leadership. Journal of Organizational Behavior, 31(4), 499-518. https://doi.org/10.1002/job.624

Sugiyono. (2010). Metode Penelitian Kuantitatif, Kualitatif dan $R \&$ D. Alfabeta. 
Tantowi, A. (2020, Mei). Kepemimpinan Moral Kepala MI Ma'arif NU 1 Pageraji Cilongok Banyumas [Taape Recorder].

Walid, M. (2018). Nilai dan Keyakinan, Kreatifitas, dan Kepemimpinan Kepala Madrasah dalam Mengelola Madrasah Ibtidaiyah Negeri Malang 1 Kota Malang. Al Ibtida: Jurnal Pendidikan Guru MI, 5(1), 107-132. http://dx.doi.org/10.24235/al.ibtida.snj.v5i1.2729

Wiyani, N. A. (2018). Kompetisi dan Strategi Pengembangan Lembaga PAUD Islam Berdaya Saing di TK Islam Al-Irsyad Banyumas. MANAGERIA: Jurnal Manajemen Pendidikan Islam, 1(1), 53-74. https://doi.org/10.14421/manageria.2016.11-04

Wiyani, N. A. (2019). Aktualisasi Prinsip Continuous Improvement dalam Kepemimpinan Responsif Kepala PAUD Islam Terpadu al-Ikhlas Bumiayu Brebes. AL-ATHFAL: JURNAL PENDIDIKAN ANAK, 5(1), 83-100. https://doi.org/10.14421/alathfal.2019.51-06

Wiyani, N. A. (2020). Menciptakan Layanan PAUD yang Prima Melalui Penerapan Praktik Activity Based Costing. Jurnal Ilmu Keluarga Dan Konsumen, 13(2), 175-186. https://doi.org/10.24156/jikk.2020.13.2.175

Woodward, I. C., \& Shaffakat, S. (2014). Understanding Values for Insightfully Aware Leadership. SSRN Electronic Journal. https://doi.org/10.2139/ssrn.2471492 